\title{
Playing with Fire: Art and the Seductive Power of Pain
}

in Suffering Art Gladly, edited by Pierre Destree and Jerrold Levinson (forthcoming)

"I almost didn't make it through Amour, which won the Oscar for Best Foreign Language Film on Sunday. It wasn't that I wasn't prepared: I knew what the movie was about and, having seen several other of Michael Haneke's movies and read about his work, was familiar with his sadistic tendencies as a filmmaker. 'Depressing' was the word used by everyone I spoke to about the film, but depressing has never been a descriptor that puts me off; it's rare that a movie, even an aggressively tragic one, depresses me. More often, I find myself simply fascinated, and even delighted, by the range of emotions cinema can capture. But Amour depressed me. It depressed me to the point that my chest felt tight, that fat tears streamed down my face as I struggled to keep my shoulders from heaving too noticeably. It depressed me to the point that I seriously contemplated escaping to the bathroom to have it out and

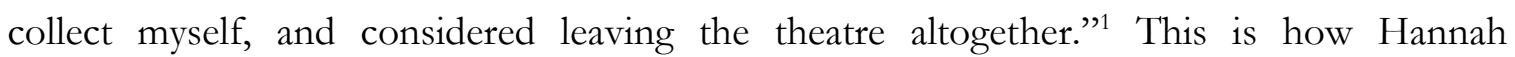
Goldfield begins a recent New Yorker column entitled "Surviving Amour." Toward the end of the essay, in an attempt to trace the origins her intense reaction, Goldfield says, "[...] my sadness arose from how close to home Amour hit." She goes on to suggest that for her, Amour hit close to home because the tragic fate of the film's main characters, Georges and Anne, resembled remarkably that of her own grandparents at the end of their lives.

Goldfield's description of her movie-going experience is likely to resonate with viewers familiar with Haneke's film. Michael Haneke's last is a wrenching, harrowing piece of cinema. Neither would Haneke himself deny the charge of "sadistic" filmmaking tendencies. He says in a recent interview, "I've been accused of 'raping' the audience in my films, and I admit to that freely - all movies assault the viewer in one way or another [...] What's different about my films is this: I'm trying to rape the viewer into independence." ${ }^{2}$ What interests me here is how an artwork that is painful to watch such as Amour may nonetheless occasion a positive, if challenging, aesthetic experience. I will be particularly, though not

\footnotetext{
${ }^{1}$ Hannah Goldfield, “Surviving Amour," New Yorker, February 26, 2013, accessed March 31, 2013, http://www.newyorker.com/online/blogs/culture/2013/02/surviving-amour.html. ${ }^{2}$ Quoted by John Wray in "The Minister of Fear," New York Times Magazine, September 2007, accessed April 1, 2013, http://www.nytimes.com/2007/09/23/magazine/23haneket.html?pagewanted $=$ all\&_r $=0$.
} 
exclusively, concerned with works that cause pain in virtue of, as Goldfield puts it, "hitting too close to home."

The question is an aspect of a problem in aesthetics detected by Hume and known in the contemporary literature as the "paradox of tragedy." ${ }^{3}$ The paradox is briefly this: some artworks give rise to intrinsically unpleasant experiences of negative emotions such as sadness, anger, fear, and grief. As a rule, we tend to avoid unpleasant experiences. (One may take the latter to be a conceptual claim: if there is some experience we tend to seek rather than to avoid, we won't call it "unpleasant"). Yet, we do not avoid artworks that provoke negative emotions in us and, indeed, often actively seek such works. We also frequently value painful art above art meant to merely entertain. Why so?

Different ways to solve the paradox have been proposed. Some accounts deny the claim that artworks give rise to unpleasant experiences. Others dispute the thesis that we have a tendency to avoid all unpleasant experiences. Hume himself took the former tack. He offers what has been called a "conversionary"4 account, on which negative emotions experienced in the context of an artwork are transformed, or "converted," into an overall positive experience. Berys Gaut takes the former tack as well but offers a revisionary view. According to Gaut, while negative emotions must, indeed, ordinarily be experienced as unpleasant in order to be properly seen as negative, it is possible for there to be individual cases in which at least some people enjoy experiencing negative emotions. Art consumption is precisely such a special case. ${ }^{5}$ Kendall Walton ${ }^{6}$ defends a view similar to Gaut's. While according to Walton, the emotions provoked by works of fiction in general are make-believe emotions, Walton

${ }^{3}$ He writes: "It seems an unaccountable pleasure which the spectators of a well-written tragedy receive from sorrow, terror, anxiety, and other passions that are in themselves disagreeable." David Hume, "Of Tragedy" in Of the Standard of Taste and Other Essays (Indianapolis: Bobbs-Merrill, 1965), 29. Of course, Aristotle had already noted that we seem to take pleasure in tragedy, but there is nothing in Aristotle's writings to suggest that Aristotle perceived any particular difficulty (let alone a paradox) here: Aristotle appears to have seen the task of the philosopher as simply that of offering a correct account of the "mechanics" of the process.

${ }^{4}$ For instance by Smuts and Levinson. See Aaron Smuts, "The Paradox of Painful Art," Journal of Aesthetic Education 41, Fall 2007 and Jerrold Levinson, "Emotion in Response to Art: A survey of the Terrain," in Emotion and the Arts ed. Mette Hjort and Sue Laver (Oxford: Oxford University Press, 1997), 20-37.

${ }^{5}$ Berys Gaut, “The Paradox of Horror," British Journal of Aesthetics 33 (1993): 333-345.

${ }^{6}$ Kendal Walton, Mimesis as Make-Believe (Cambridge, MA: Harvard University Press, 1990), Section

7.3. 
suggests that we do not need to resort to the deflationist theory of emotion in art in order to solve the paradox of tragedy (and of painful art, more generally). ${ }^{7}$ John Morreall's "control thesis" view can be placed in this category as well: according to Morreall, control we have over the pain in the context of art changes the emotional valence valence

Then there are those theories that deny that we have a tendency to avoid all unpleasant experiences. They can be said to take their cue from an ordinary observation: sometimes, we see value in a painful and unpleasant experience and deliberately choose to undergo rather than avoid it. Thus, some women choose to give birth without anesthesia. Some bereaved spouses refuse to take any medication that would help blunt the feelings of grief. We may embrace such experiences for a variety of reasons - because they are meaningful to us in some way, because they harmonize with our self-conception, because they offer cognitive benefits, etcetera. ${ }^{8}$ In principle, it is possible that there are similar reasons for us to seek works we know will cause us pain. Susan Feagin's version of the compensation theory, for instance, is an elaboration of this possibility. ${ }^{9}$ Feagin argues that the experience of negative emotions in the context of an artwork is a complex attitude, which consists of a direct response and a meta-response. On the first-order level, we may be saddened by an artwork and pained by it, but on the meta-level, we may recognize our first-order responses as appropriate, and be pleased by their appropriateness. If, contrariwise, I detect that I am unmoved by human tragedy, this may be a depressing self-discovery, which suggests that I

\footnotetext{
${ }^{7}$ On the deflationist theory, we know that the objects of our art-generated emotions are not real, and so our emotions themselves can't be real or full-fledged either. They are much like the emotions of children who have designated a certain tree to be a bear, and then approach the tree carefully, in fear and awe. This view is criticized by, among others, Noël Carroll in "On Kendal Walton's Mimesis as Make-Believe," Philosophy and Phenomenological Research 51:2 (1991): 383-387, 384. Note that it is possible to reject Walton's particular solution to the paradox of painful art but offer a solution along Waltonian lines, one based on the premise that the painful emotions generated by tragic art and horror are merely make-believe emotions. One such a view, we are never truly afraid, sad, or bereaved, in virtue of consuming a fictional work of art.

${ }^{8}$ A number of authors have remarked that suffering may be endured gladly and often ceases to be suffering altogether if seen as meaningful. For instance, Nietzsche writes: "Man, the bravest of animals and the one most accustomed to suffering, does not repudiate suffering as such; he desires it, he even seeks it out, provided he is shown a meaning for it, a purpose for it," On the Genealogy of Morals trans. Walter Kaufmann and R.J. Hollingdale, in On the Genealogy of Morals and Ecce Homo (New York: Random House, 1967), 3:28. Viktor Frankl makes an almost identical point in Man's Search for Meaning (Boston: Beacon Press, 2006).

9 Susan Feagin, “The Pleasures of Tragedy," American Philosophical Quarterly 20 (1993): 95-104. Jerry

Levinson labels Feagin's view "organicist." See Levinson, "Emotion."
} 
resemble a machine lacking the normal human emotions. Katerina Bantinaki, similarly, puts forth a moderate hedonic account on which, while painful art does give rise to intrinsically unpleasant emotions, the overall experience we derive out of the engagement with painful works is positive.

Smuts offers an a-hedonic version of the compensatory view. He argues that we can find experiences both unpleasant and perfectly desirable: art experience is complex, and though it may have painful aspects, it may, simultaneously, be desirable as a whole, a view Smuts labels "the rich experience view." ${ }^{10}$ Noël Carroll, on the other hand, denies the universal avoidance thesis by arguing that the negative emotions in art, while intrinsically unpleasant, are instrumental in enabling us to experience other, positive and pleasant emotions. ${ }^{11}$ Much like the roller skater who may not enjoy the fear accompanying the ride but may enjoy the thrill and recognize that one cannot have the thrill without the fear, so the viewer of a horror film does not enjoy being scared but, rather, enjoys having her curiosity piqued and then satisfied, and she cannot have her curiosity piqued and satisfied without being scared.

It is not my purpose here to arbitrate among these different theories. This is partly because I am interested in one particular class of painful experiences - namely, those that are painful by virtue of "hitting too close to home" - and partly because I believe that artworks that occasion negative emotions can be enjoyed for a variety of reasons. While we may have a fruitful discussion regarding individual cases, I am skeptical with regard to the possibility of a unified theory. It seems to me likely, for instance, that films portraying a lot of violence and killing may be doing for their viewers what boxing and violent sports appear to do for theirs: helping re-channel aggressive drives. ${ }^{12}$ Young people who watch and report enjoying a film

\footnotetext{
${ }^{10}$ Aaron Smuts,

${ }^{11}$ Noël Carroll, "Enjoying Horror Fictions: Reply to Gaut," British Journal of Aesthetics 35 (1995): 6772

${ }^{12}$ A recent study conducted by Anne Bartsch from the University of Augsburg, Germany and Louise Mares from the University of Wisconsin-Madison suggests also that audiences are more attracted to gory movies, featuring bloodshed, if they expect the narratives to be thought-provoking. The study was reported in "What Attracts People to Violent Movies," Science Daily, March 28, 2013, accessed April 1, 2013, http://www.sciencedaily.com/releases/2013/03/130328091750.htm. The result is interesting and provides some support for cognitivist versions of compensation theories, but we must be cautious what conclusions, precisely, we draw from the study: while it may well be true that people are more likely to watch a thought-provoking violent film than they are to watch violence for
} 
meant to nauseate, such as Pink Flamingos, are probably pleased with their own rebellion against the comfort and convenience of art that appeals to middle-class sensibility. ${ }^{13}$ Again, a person who enjoys a horror film or novel may enjoy it for reasons similar to those which Graham Greene reports to have had when making a decision to enroll in the army and go to the front: because to be scared is better than to be bored.

Some, though not all, of the explanations just listed are of little help when it comes to the sorts of cases that interest me. The revisionary view, for instance, will not do. The emotions we experience when watching a film such as Amour are genuine and genuinely unpleasant (this is why a viewer may, like Goldfield, be tempted to leave the theater). They seem to be largely out of our control. Neither would it do to say, à la Feagin, that we are at the metalevel pleased with our first-order response. For in this case, our first-order response is sadness and fear in the face of the prospect of aging. Why should we be pleased by this sadness and fear? After all, if one can think about aging (and watch the movie Amour) without the sorrow, that would probably be a good thing. Thus, neither a deflationary nor a revisionary explanation seems to be available, and at least one version of the organicist view, namely Feagin's, is not of help either. This is not to suggest that none of the views just listed can offer any guidance. As we shall see, both the compensatory and other versions of the organicist explanation may still be available.

Before I turn to the question how and why viewers may enjoy painful works, I wish to ask what may tempt an artist to try to cause viewers pain, to "rape" them, as Haneke claims. This may give us an insight into how the sorts of works we are discussing function.

Speaking from personal experience, I thought I knew exactly what Haneke meant with the "rape" metaphor. And I thought I knew because, although I am a professor and not a movie director, I myself adopt a similar strategy with students in class on a much smaller scale. I would not say I try to "rape students into independence," but I certainly try to "wake them up," and this often requires disturbing them a little. For instance, the topic of discussion in one of my recent seminars was racial segregation. Now, there are safe ways to approach this

the sake of violence, many appear to watch violent films that are not thought-provoking (which is why many such films are produced on a regular basis).

${ }^{13}$ Carroll makes a suggestion along these lines as well. See Carroll, "Reply to Gaut," 70. 
topic. One is to present the data in a matter-of-fact fashion: research suggests that there is a slight but steady trend toward racial integration. The trend is especially visible in big cities, such as LA and NYC. One could also deplore the speed with which things are changing or salute the modest but steady progress. I could have done one of these things. To do so would have been to "play it safe" - to proceed on the assumption that both I and my students are free of racial bias, guilty of nothing, and that we simply happen to have found ourselves in which racial biases exist.

It may well be true that some students are, indeed, free of bias. It is unlikely that most of them are. After all, the status quo cannot be sustained if the majority of people did not go along with it, and there is no reason to think that my students are mostly outliers. There is also direct evidence that most people do, indeed, have racial biases, if only implicit ones. ${ }^{14}$ Perhaps more importantly for my instructional purposes, however, assuming all these things would make for a conventional and somewhat uninteresting class. For those reasons, I chose another approach. I dropped the assumption that everyone present is deeply committed to racial equality and invited them to imagine a neighborhood that's $80 \%$ white and $20 \%$ black. And to imagine further that more black families start moving into that neighborhood, gradually changing the ratio until it becomes 50\% black and 50\% white. I then asked students to estimate what percent of white residents will leave the neighborhood. The question made some of them visibly uncomfortable, but it also "woke them up." They grew even more uncomfortable when I asked them whether they, personally, regardless of race, would leave a neighborhood because they don't like the blacks to whites ratio, and what ratio would make them uncomfortable. I knew I was venturing into dangerous territory, but I also thought that the risk was worth it.

It was. The questions prompted a lively discussion, and even normally taciturn students spoke up. Some emailed me later to say the class was exceptional. What I would like to suggest here is that there is a parallel between a daring lecture and a daring artwork, and that the parallel can help shed light on how painful art functions. When you disturb viewers, you engage their emotions, and you make them pay attention to the artwork and to care about its

\footnotetext{
${ }^{14}$ See, for instance, John T. Jost et al. "The Existence of Implicit Bias is Beyond Reasonable Doubt: A Refutation of Ideological and Methodological Objections and Executive Summary of Ten Studies that No Manager Should Ignore," Research in Organizational Behavior 29 (2009): 39 - 69.
} 
content. Both paying attention and caring are necessary features of a powerful art experience. So a real and powerful art experience may be painful and disturbing.

One form art's challenge may take is the suggestion, recurring in some of the most memorable works of art, that ordinary people, people just like you and me, may have terrible thoughts and impulses or else lack the kinds of attitudes we expect them to have. Consider, for instance, Ibsen's exceptional play Little Eyolf. In it, the young and physically disabled son of a respectable, middle-class couple drowns. The boy drowns in front of the eyes of a number of other children. The mother and father talk about why none of the other children came to the boy's rescue. One of them says, paraphrasing, "Well, you and I cannot swim, would you have jumped?" to which the other replies, "I don't know." This is a chilling scene. How certain are we that we will be any different from the parents portrayed? More frightening yet, that our parents would be any different? We dare not ask.

The messages of powerful art are not things we can directly and comfortably say to each other. Certainly not to strangers, but likely, not to those we are closest with, or even to ourselves. Only art is allowed to give voice to them, thanks to its fictional or symbolic nature. Since an artwork is typically not about any particular person, we all have plausible deniability. Yet, we only perceive the artwork as compelling because we sense it is about all of us, despite, or perhaps because of, the fact that it is about no one in particular.

Note, however, that here we are not yet talking of art that's "too close to home." For suppose, by contrast, a couple whose son has drowned watches the play. And suppose that neither of the two parents can swim and both are afraid of the water. The two are likely to find the scene so disturbing as to make them incapable of focusing on the rest of the play or enjoying any of it. When we retain a critical distance, the disturbance in question is primarily moral. When the work hits too close to home and such distance is reduced, the disturbance is psychological. In the former case, we feel that the challenge is addressed to everyone, not primarily to us. There is, thus, an element of truth in the inspired by Hobbes (and at another 
remote, Lucretius) view on which tragedy reminds us how fortunate we are, and the reminder is pleasant. ${ }^{15}$

But then what about artworks that do hit too close to home? There are two different ways in which an artwork can pain us in a personal way. The first way is by making us its primary object by coincidence. A woman in Anna Karenina's situation - in a loveless marriage and in love with someone else, a woman who struggles to get a divorce only to find that her lover begins cheating on her as soon as she and her lover can be together without restrictions, may find that the proximity between the narrative and her own life makes watching too painful and interferes with her aesthetic experience of that narrative. Note that such coincidences can happen even when we watch artworks that are not at all meant to provoke negative emotions, in general. For instance, watching a feel-good movie about the value of friendship may make one feel a lot of pain if one has just lost a friendship to a bitter verbal exchange. Such cases do not give rise to a paradox, since we do not seek such experiences and, indeed, deliberately try to avoid them. "I couldn't continue watching," or "It was just too painful" are common reactions in cases such as these. The viewer who happens to be personally pained in this way is not the primary target audience of the art work. The writer may, of course, have private reasons to hope that some particular person will read the work and recognize himself in it, but those reasons are not an integral part of the author's artistic intention.

There is, however, a second way in which we can be pained and disturbed. An artwork may be explicitly meant to disturb its audience, and in very profound ways. It may be meant to hit

${ }^{15}$ Hobbes himself did not directly address the paradox of tragedy, but he elaborated on Lucretius's observation that we appear to take a certain amount of enjoyment in contemplating the suffering of others. He writes: "From what passion proceedeth it, that men take pleasure to behold from the shore the danger of them that are at sea in a tempest, or in fight, or from a safe castle to behold two armies charge one another in the field? It is certainly in the whole sum joy. Else men would never flock to such a spectacle. Nevertheless there is in it both joy and grief. For as there is novelty and remembrance of [ones] own security present, which is delight; so is there also pity, which is grief. But the delight is so far predominant, that men usually are content in such a case to be spectators of the misery of their friends," Thomas Hobbes, The Elements of Law, in John Gaskin ed. The Elements of Law, Natural and Politic (Oxford: Oxford University Press, 1990), 9:19. Lucretius makes essentially the same point: "What joy it is, when out at sea the storm winds are lashing the waters, to gaze from the shore at the heavy stress some other man is enduring! Not that anyone's afflictions are in themselves a source of delight; but to realize from what troubles you yourself are free is a joy indeed," Lucretius, The Nature of the Universe (Harmondsworth: Penguin Books, 1951), 1-5:60. 
too close to home for everybody. The viewer who, not being herself in Anna Karenina's situation, commiserates with Anna's fate does so from a "safe place," as it were - knowing that the narrative does not apply to her. The pain she shares is truly someone else's pain, and while others' pain may pain us, it's rarely quite in the way in which our own pains do.

Note, incidentally, that there are two different levels of emotional deflation (or reduction) operating here: when someone else suffers, the pain we feel for that person is, typically, not as acute as it would be in our own case (of course, it depends on who the person is - we may also love someone so much that we'd be more pained to see that person suffer than to suffer ourselves). This level of deflation is present in real life, for instance, in our experience of reading tragic stories in the newspapers. Newspapers often print tragic stories, presumably because readers read them. One may wonder why anyone reads them. The answer must, at least in part, have to do with the fact that the tragedy has happened to someone else and we can commiserate from a distance, from our own safe havens. There is a second level of deflation in art which has to do with the fact that the object of tragedy is fictional. This helps further minimize the pain and produce an overall positive experience.

But what if there is no real deflation? What if the viewer is the object of unabashedly sadistic film-making or novel-writing tendencies? How can we enjoy having genuine pain? This is the puzzle that interests me. How can we derive aesthetic enjoyment out of feeling genuinely pained and disturbed?

I will begin by noting first that art meant to pain everyone must do so by virtue of addressing common human concerns such as death and aging, rather than concerns specific to this or that person's case, for instance, the difficulties in being a lawyer. And these concerns must be concerns we do not, frequently, address. This is precisely what daring works such as Haneke's Amour do: they challenge the boundaries of acceptable conversation. We do not like to openly discuss issues of aging. We try to cover up the signs of it. There are probably a few hundred pictures of young and dashing people for every photo of an elderly person on the internet. And while a Google search for "elderly couples" delivers photos of the latter as well, the photos readily available are of happy, healthy, smiling retirees, holding hands or embracing each other. The kinds of radiant pictures one sees on postcards and, 
occasionally, on the food product packages of family-owned farms. It is against this background that Amour can be said to "rape" the viewer. Amour begins with an image of a dignified, middle-class couple, Georges and Anne, who come back from a moving classical music concert, which both of them have thoroughly enjoyed. The enjoyment is obviously heightened by the fact it is shared: Georges and Anne appear connected by a myriad links of intimacy, and the pleasure felt by each is vicariously felt by the other, enhancing the other's own positive experience. The very next morning, however, Anne has a stroke. It's the beginning of the end. Anne is soon paralyzed on the right side, and then gradually loses her mental capacities. She becomes a shadow of her former self. Indeed, her "self" gradually disintegrates. The two do not talk about her condition. It would be too painful to do so, and there is no point in doing it either: talking about the pain will do no good. Both Georges and Anne know that they will never walk to the concert hall hand-in hand again and Anne who, as we learn later, is retired music teacher (as well as the teacher of the brilliant concert pianist whose concert she and Georges are listening to in the opening scene) will never play the piano again; but each of them endures silently the suffering which this knowledge occasions. Georges sometimes has visions of Anne playing the piano. Things go steadily downhill, until one day, Georges cannot cope anymore and, faithful to a promise he's made to Anne not to let her die in a hospital or a nursing home, smothers her with his own hands.

There is a beautiful Leonard Cohen song in which Cohen sings, "Dance me to the end of love." Amour makes us painfully aware of that we cannot "dance" each other to the end of love. In one of Amour's most striking scenes, Georges props his paralyzed wife, helping her move from one place to another. The ritual resembles an embrace, and is as close to an embrace as the couple ever come after Anne's stroke. Love does not end with a dance - it ends with one partner propping the other so the other can go to the restroom. And very soon, even this painful shadow of an embrace is not an option. There is no way to live happily ever after, not because passion may subside - if we are lucky, as Georges and Anne are, it will not - but because life will come to an end, and the ending isn't likely to be happy. Amour is a film about the painful end of love.

Goldfield tells us that for her, Amour struck too close to home, because it reminded her of her grandparents' fate. And it is probably true that her experience was more intense on 
account of the fact that it conjured up images of her own grandmother and grandfather. At bottom, however, Amour disturbs not by coincidence - not because it happens to resemble this or that piece of one's life - but as a matter of course. You may have not had grandparents who suffered at the end of their lives - either because you weren't privy to your grandparents' suffering (you may not have been close enough with them to go see them or they may have, like Georges and Anne, deliberately tried to avoid being seen in a humiliating condition), or because your grandparents are still healthy - but you probably know of some couple like Georges and Anne. More importantly, you know you too are likely to end up like them. And that, if things turn out well, that is, if you find love. The alternative is to simply die alone. Goldfield acknowledges all that as well. She ends her essay by saying: "As I sat crying in the movie theater, I realized that if I was lucky enough [...] to find love that lasted, I would be unlucky enough to see it end."16

That love comes to an end, and an awfully painful one at that is not what we want to believe, and ordinarily, we are careful to avoid reminders that this may be so. Amour, thus, works on us by transgressing boundaries we make careful effort to observe. Imagine, by contrast, a society in which we openly confront the terrible side of aging daily. In that society, a film such as Amour will not be as powerful as it is for us. (Probably it is even beautiful, rather than painful, for medical staff working in nursing homes and accustomed to see life ending).

Daring art, thus, disturbs by challenging conventional conversational boundaries, as well as boundaries of thought. Not everyone will be up for the challenge. This is why those who are will experience a sense of freedom and liberation. The freedom can be intoxicating: in art, we can give voice to any concerns we don't know quite how to address. Relatedly, the reader or viewer of painful art feels respected: handled without gloves, treated like a grown-up who can be presumed to be capable of "taking it." This is another reason why the overall experience is seen as positive. Finally, a reader or viewer of such art may take delight in her own ability to retain her aesthetic sense even in the face of pain, and to appreciate an artwork as an artwork, not letting the pain overwhelm her and make her incapable of judging aesthetically.

16 Goldfield, “Surviving Amour.” 
There is more. An element of what views such as those of expression theorists like Collingwood claim may also be correct. Carroll rejects the expressionist suggestion that works of horror effect a beneficial transformation of harmful emotions by saying that horror films truly scare their audience, instead of "lightening up," in Collingwood's phrase, fears the audience may already harbor. But Carroll is at least partly wrong: horror films may scare us, but they may at the same time serve to assuage latent fears, such as fear of death. By confronting what we find scariest, we tame the fears and, as it were, domesticate them. Gaut agrees partly with Carroll here, arguing that if horror movies could "lighten up" fears, we would enjoy watching them when we are most frightened. But this is not so: it may be that we have to be in the right frame of mind in order to confront our dormant fears - it won't follow from this that we are not really confronting those fears just because we can't watch the fear-provoking fictions unless in a robust state of mind.

Similar considerations apply to the sorts of cases I have had in mind: painful art may help us confront our latent fear of aging, for instance, although, in all likelihood, we must be in a robust state of mind to derive any enjoyment from powerful artworks whose benefits pass by way of, or must be purchased by, real pain on the part of their audiences.

There is something else as well. In violating conversational restrictions and exposing our deepest fears and our darkest side, art helps connect each of us to the rest of humanity. This is another positive function which painful art serves. While each of us knows, intellectually, that it is not only him or her, that everyone will age and die, we have very little serious shared conversation about these things and, as a consequence, each of us may feel lonely in his or her predicament. The loneliness will be mitigated if one has a partner, but it won't go away entirely, since a couple too may feel lonely, but likely less so if enabled to ponder the existence of other couples in a similar plight. Some truths about being human are so heavy that we need to share them not just with one other, but with many others.

I have underlined here that painful art feeds on conversational restrictions. This leads to an interesting question. If we progress to the point of abandoning such restrictions, if we become able to talk about everything, what kind of art will there be? John Stuart Mill suggested once that the discovery of all truths will be the end of liberty and democracy, since 
liberty and democracy require diversity of opinions, and that's possible only if we don't know everything. Perhaps, we may say, similarly, that the abolition of all conversational boundaries could spell the end of art, or at least of powerful and provocative art.

That does not seem like a desirable prospect. Just as we want truth but do not want to be omniscient, because we fear that if we are, life will lose its meaning, so we want to play with fire and gain more independence but not to become completely independent, like gods who cannot be burned by fire. This suggests a final reason why we may enjoy the experience of pain: pain assures us that we are human.

Mill, incidentally, would agree with this fully. In a chapter entitled "A Crisis in My Mental History" in his Autobiography, he describes an onset of depression, triggered by the thought that if all the objects of his thoughts and pursuits were realized, this would bring him no joy, and life would lose its meaning. He then falls into a state which, in Mill's own words, was best captured by Coleridge's poem "Dejection":

"A grief without a pang, void, dark and drear,

A drowsy, stifled, unimpassioned grief,

Which finds no natural outlet or relief

In word, or sigh, or tear."

He then goes on to tell us that what helped him overcome the state of depression was being moved to tears when reading the Memoires of Jean-Francois Marmontel. Crying over the passage in which Marmontel describes his father's death, Mill says, made his being "grow lighter" and gave him hope, because he was assured he was not "a stock or a stone." We can take this a step further. It is probably safe to assume that we all have a latent fear of losing the capacity to feel, and of turning into stones or the like. Painful art helps assuage this fear by making us feel, and most unmistakably. ${ }^{17}$

${ }^{17}$ Levinson makes a similar point in "Music and Negative Emotion" [1982], reprinted in Music, Art, and Metaphysics, 2nd ed. (Oxford University Press, 2010). 
